\title{
Observed and simulated variability of the AMOC at $26^{\circ} \mathrm{N}$ and $41^{\circ} \mathrm{N}$
}

\author{
C. Mielke, ${ }^{1}$ E. Frajka-Williams, ${ }^{2}$ and J. Baehr ${ }^{1}$ \\ Received 3 January 2013; revised 4 February 2013; accepted 6 February 2013; published 27 March 2013.
}

[1] Time series of the observational estimate of the Atlantic meridional overturning circulation (AMOC) have recently become available, but so far, no contemporaneous relation has been documented between them. Here, we analyze the variability of the $26^{\circ} \mathrm{N}$ Rapid Climate Change programme (RAPID) and the $41^{\circ} \mathrm{N}$ Argo-based AMOC estimates on seasonal timescales, and we compare them to a simulation from a high-resolution National Centers for Environmental Prediction (NCEP)-forced ocean model. In our analysis of the observed time series, we find that the seasonal cycles of the non-Ekman component of the AMOC between $26^{\circ} \mathrm{N}$ and $41^{\circ} \mathrm{N}$ are 180 -degrees out-of-phase. Removing the mean seasonal cycle from each time series, the residuals have a non-stationary covariability. Our results demonstrate that the AMOC is meridionally covariable between $26^{\circ} \mathrm{N}$ and $41^{\circ} \mathrm{N}$ at seasonal timescales. We find the same covariability in the model, although the phasing differs from the observed phasing. This may offer the possibility of inferring AMOC variations and associated climate anomalies throughout the North Atlantic from discontinuous observations. Citation: C. Mielke, E. Frajka-Williams, and J. Baehr (2013), Observed and simulated variability of the AMOC at $26^{\circ} \mathrm{N}$ and $41^{\circ} \mathrm{N}$, Geophys. Res. Lett., 40, 1159-1164, doi:10.1002/grl.50233.

\section{Introduction}

[2] With a northward heat transport of up to $1.3 \mathrm{PW}$ [Ganachaud and Wunsch, 2003], the Atlantic meridional overturning circulation (AMOC) is one of the prominent components of today's climate and has a strong influence on the climate of North America and Europe (e.g., [Sutton and Hodson, 2005]). Seasonal AMOC variations impact the seasonal heat storage and sea surface temperature in the North Atlantic, which affects climate phenomena such as North Atlantic hurricane activity [Zhang and Delworth, 2006] and the North Atlantic Oscillation (NAO) [Taws et al., 2011]. The AMOC variability has been the subject of many, mostly model-based studies over the years, whether at a single location [Böning et al., 2001; Baehr et al., 2009] or across several latitudes [Bryan, 1982; Balan Sarojini et al., 2011; Munoz et al., 2011]. It has been suggested that the AMOC variability might be gyre-

\footnotetext{
All Supporting Information may be found in the online version of this article.

${ }^{1}$ Institute of Oceanography, University of Hamburg, Hamburg, Germany.

${ }^{2}$ National Oceanography Centre, University of Southampton, Southampton, UK.
}

Corresponding author: C. Mielke, Institute of Oceanography, University of Hamburg, Bundesstrasse 53, 20146 Hamburg, Germany. (charlotte.mielke@zmaw.de)

(C)2013. American Geophysical Union. All Rights Reserved. 0094-8276/13/10.1002/grl.50233 specific, with higher variability in the subtropical gyre [Bingham et al., 2007; Lozier et al., 2010], but coherence across the gyres has so far not been identified on seasonal timescales.

[3] Continuous AMOC estimates are at present restricted to two latitudes $\left(26^{\circ} \mathrm{N}\right.$ and $\left.41^{\circ} \mathrm{N}\right)$, [Cunningham et al., 2007; Willis, 2010], and they have only recently become available. Therefore, a joint analysis of two observed, albeit short, AMOC time series is now possible for the first time. In agreement with the studies mentioned above, no relation has yet been documented between these two time series.

[4] Here, we analyze the seasonal to interannual variability of the AMOC transport time series at $26^{\circ} \mathrm{N}$ and $41^{\circ} \mathrm{N}$ from both observations and a numerical model. As the underlying mechanisms will be subject of research for many years to come, the scope of the present study is to describe and compare the meridional covariability of the seasonal and interannual variability in the model and observations as a reference for further investigations.

\section{Description of Observations, Model and Methods}

[5] Observations at $26^{\circ} \mathrm{N}$ are from the RAPID/MOCHA array [Cunningham et al., 2007]. The array was tested in numerical models to ensure that it can indeed capture the mean and short-term variability of the overturning [Hirschi et al., 2003; Baehr et al., 2004]. Data are available at daily resolution from April 2004 to December 2010 and have so far been the subject of several studies (e.g., [Kanzow et al., 2007, 2010; Rayner et al., 2011; McCarthy et al., 2012]). The AMOC transport is calculated as the sum of Florida Straits transport, Ekman transport and upper mid-ocean transport derived from moorings placed across $26^{\circ} \mathrm{N}$. The Ekman transport is calculated from the ERA-Interim wind product [Dee et al., 2011], but no significant differences are found if National Centers for Environmental Prediction (NCEP) reanalysis data [Kalnay et al., 1996] are used (see Figure S1 in the Supplementary Information). Here, we use monthly mean data, smoothed by a three-month moving average.

[6] The AMOC estimates at $41^{\circ} \mathrm{N}$ are from Willis [2010] and are computed using Argo floats and altimeter data. Data are available as three-month running means, from January 2002 to September 2010. The Ekman transport is computed from NCEP reanalysis data [Kalnay et al., 1996].

[7] The reader should be aware that although both time series will be treated equally in the following analysis, there are fundamental differences between the two estimates: At $26^{\circ} \mathrm{N}$, the AMOC is calculated as the maximum of the overturning circulation, using profiles of density at the eastern and western boundary and the Mid-Atlantic Ridge and applying a compensation velocity by assuming zero net transport [Kanzow et al., 2007, 2010]. At $41^{\circ} \mathrm{N}$, a monthly 
(a)

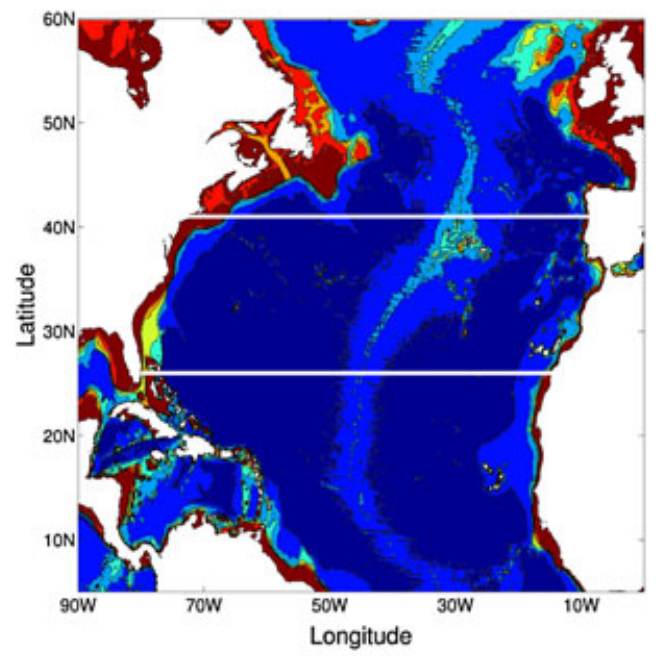

(c)

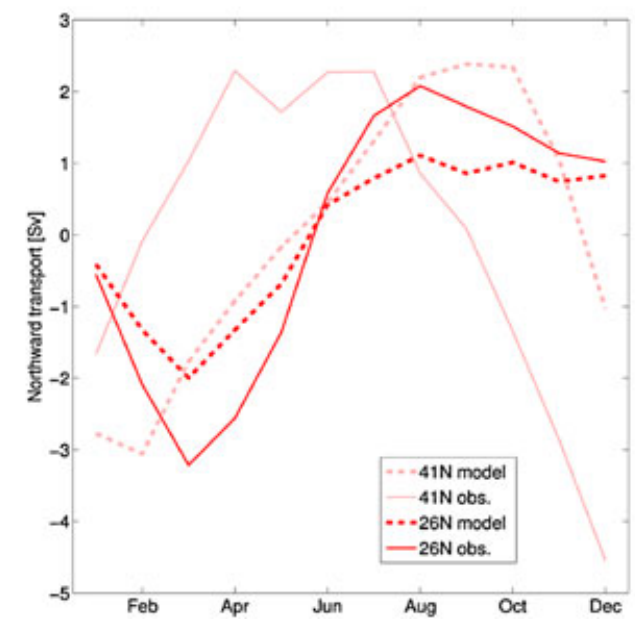

(b)

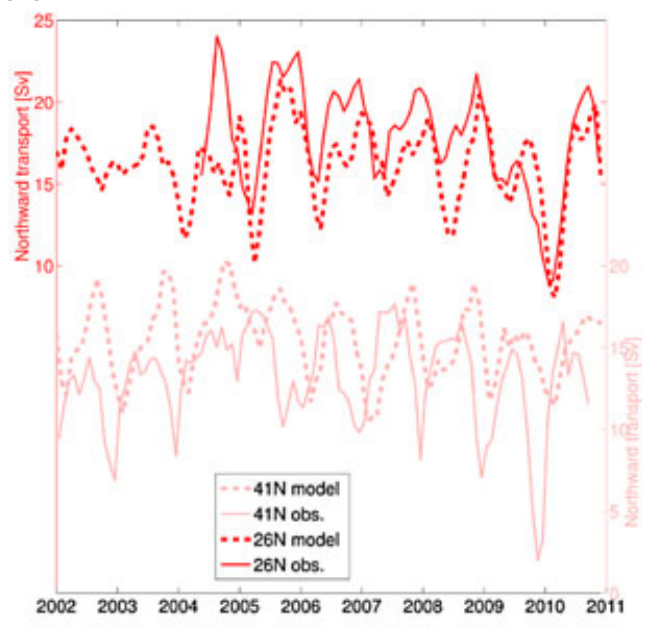

(d)

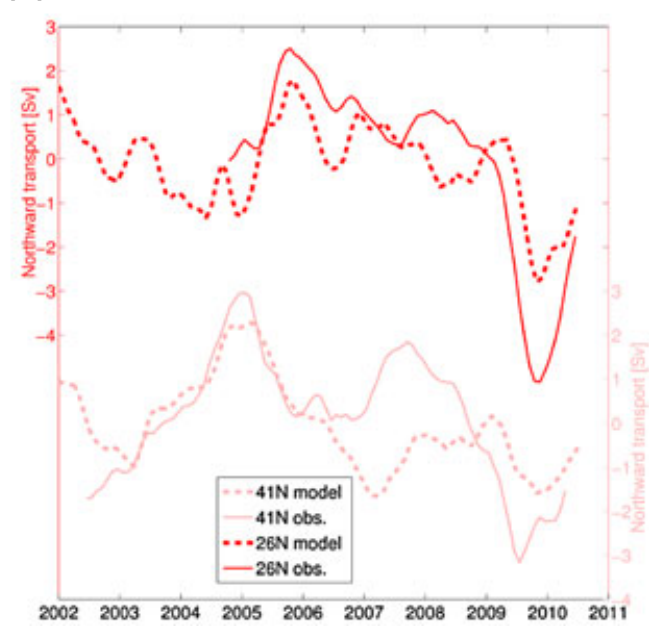

Figure 1. (a) Bathymetry of the North Atlantic ocean in the Max-Planck-Institute (MPI) ocean model (STORM project) after interpolation and latitudes of interest, (b) observed (solid) and model (dashed) Atlantic meridional overturning circulation (AMOC) annual cycle at $26^{\circ} \mathrm{N}$ (dark) and $41^{\circ} \mathrm{N}$ (light), (c) AMOC time series, (d) AMOC time series with seasonal cycle removed.

time series of density from the surface to $2000 \mathrm{~m}$ is derived from Argo data, referencing the geostrophic shear using a level of known motion from the mapped Argo parking depth velocities and altimetry [Willis and Fu, 2008] . The AMOC is then calculated by integrating from the surface to $1130 \mathrm{~m}$, the average depth of no motion at $41^{\circ} \mathrm{N}$ [Willis, 2010].

[8] The model output stems from a high resolution ocean model simulation with the MPI ocean model [Jungclaus et al., 2006; Marsland et al., 2003] in a setup with a horizontal resolution of $0.1^{\circ}$ and 80 vertical levels $(10-280 \mathrm{~m}$ thickness, Figure 1a). The simulation is forced by 6-hourly NCEP reanalysis data, and covers the time period 1948-2010 (von Storch [2012], section 1 of the supplementary material). Here, we focus on the period that overlaps with the $41^{\circ} \mathrm{N}$ observations (2002-2010). The overturning stream function is directly calculated from the velocities in the model, and the AMOC is defined as the vertical maximum of the stream function. The Ekman transport is calculated from the zonal wind stress component $\tau_{x}$ as $\psi_{\text {Ekman }}=-\int \frac{\tau_{x}}{\rho f} \mathrm{~d} x$, where $\rho$ is the density and $f$ is the Coriolis parameter. The model output is smoothed to three-month running means for comparison with the observations.

[9] For both latitudes, we calculate the wind stress curl from NCEP reanalysis data [Kalnay et al., 1996], which we refer to as the observed wind stress curl. For the model, a wind stress curl is calculated from the output wind stress fields between $15^{\circ} \mathrm{N}$ and $50^{\circ} \mathrm{N}$. In both cases, the Sverdrup transport is calculated as the zonal integral of the wind stress curl, following standard theory: $\psi_{\text {Sverdrup }}=$ $\int \frac{\operatorname{curl}_{z} \tau}{\beta} \mathrm{d} x$, where $\beta$ is the rate of change of the Coriolis parameter with latitude. In the following, we will not distinguish between observed and modelled Sverdrup transport, as they are not substantially different because the NCEP data are used to force the model run. For completeness, both curves are displayed in the figures. 
Table 1. Mean Values, Standard Deviations and Seasonal Range in Parentheses for the Transports Discussed in This Paper (All Values Are in Sv).

\begin{tabular}{lllclc}
\hline & & MOC & Ekman & AMOC-Ekman & Sverdrup \\
\hline $26^{\circ} \mathrm{N}$ & Obs. & $17.9 \pm 3.2(5.3)$ & $3.5 \pm 1.5(3.0)$ & $15.1 \pm 2.1(2.8)$ & $-25.3 \pm 6.5(8.6)$ \\
& Model & $16.4 \pm 2.5(3.1)$ & $3.7 \pm 1.4(1.7)$ & $12.6 \pm 1.7(2.0)$ & $-19.8 \pm 6.7(9.1)$ \\
$41^{\circ} \mathrm{N}$ & Obs. & $13.2 \pm 3.0(6.8)$ & $-2.6 \pm 1.7(3.6)$ & $15.8 \pm 2.1(4.3)$ & $-6.0 \pm 17.0(11.1)$ \\
& Model & $15.2 \pm 2.4(5.4)$ & $-2.3 \pm 1.7(3.7)$ & $17.8 \pm 1.2(2.4)$ & $-0.3 \pm 10.2(7.8)$ \\
\hline
\end{tabular}

(a)

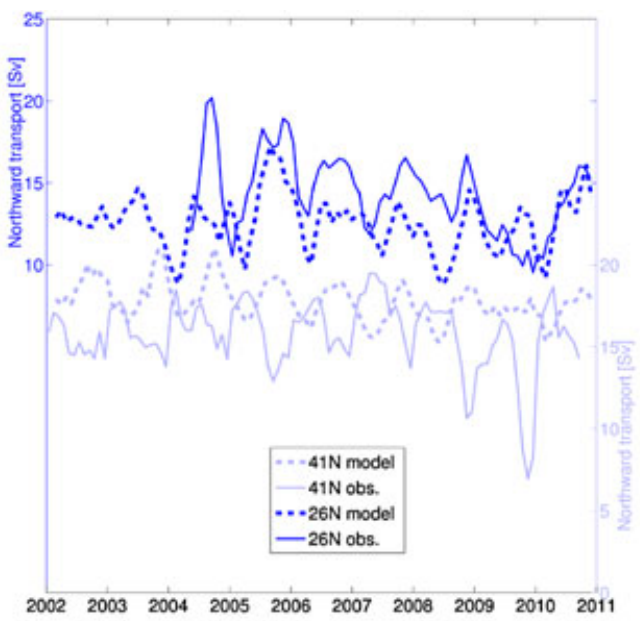

(c)

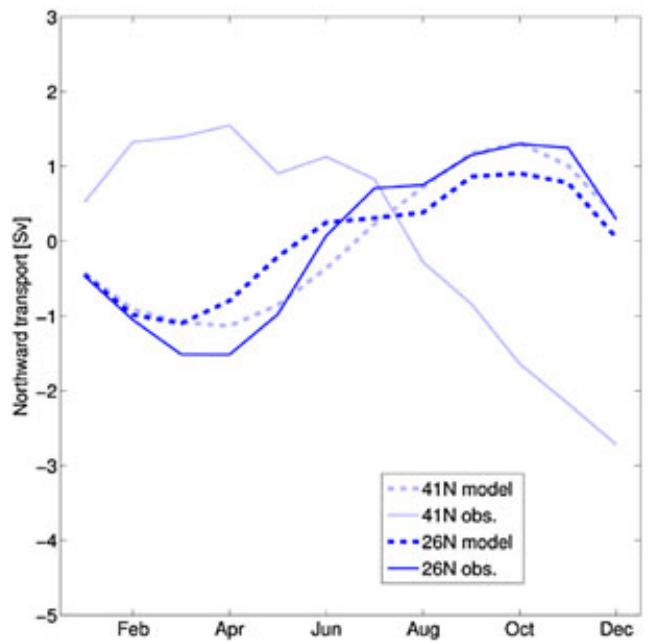

(b)

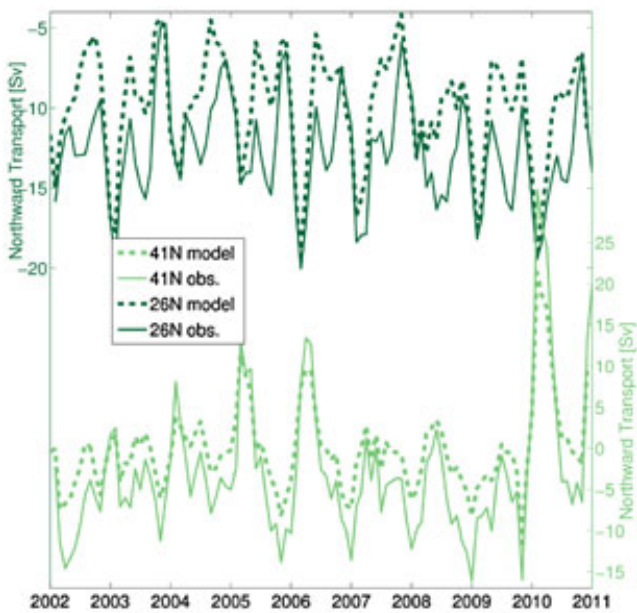

(d)

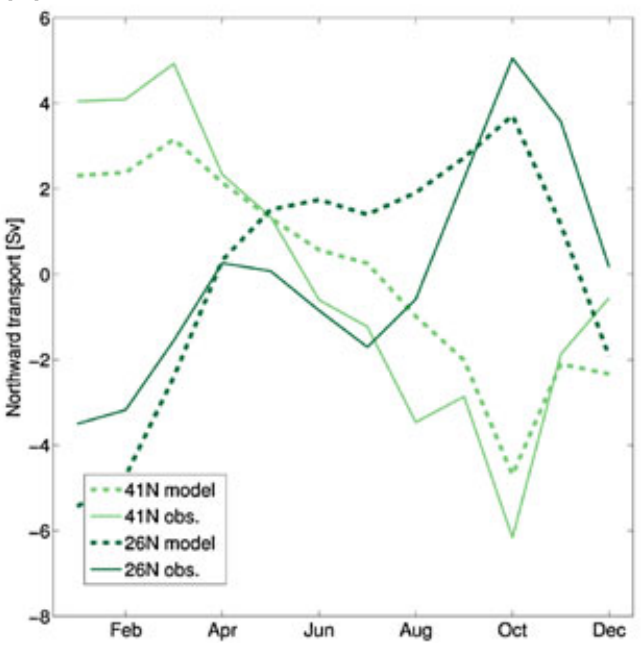

Figure 2. Time series and mean annual cycle anomalies of observed (solid) and model (dashed) AMOC-Ekman and Sverdrup transport at $26^{\circ} \mathrm{N}$ (dark) and $41^{\circ} \mathrm{N}$ (light): (a) AMOC-Ekman time series, (b) Sverdrup transport time series, (c) AMOC-Ekman annual cycle anomalies, (d) Sverdrup transport annual cycle anomalies.

\section{Latitudinal Covariability at Seasonal Timescales}

[10] At $26^{\circ} \mathrm{N}$, the observed AMOC transport has a timemean value of $18 \mathrm{~Sv}\left(1 \mathrm{~Sv}=10^{6} \mathrm{~m}^{3} \mathrm{~s}^{-1}\right.$, for exact values and standard deviations for all transports, see Table 1, all values are calculated from the smoothed time series). At $41^{\circ} \mathrm{N}$, the observed AMOC has a smaller time-mean value (about $13 \mathrm{~Sv}$ ), but a higher standard deviation than at $26^{\circ} \mathrm{N}$. However, we find no obvious contemporaneous relation between the observed AMOC estimates at these latitudes (Figure 1b), although — given the shortness of the available time series-lead-lag relationships on longer timescales cannot be excluded. The observed AMOC seasonal cycle (Figure 1c) at $26^{\circ} \mathrm{N}$ agrees well with the seasonal cycle computed by Kanzow et al. [2010] using only data from 2004-2008.

[11] To analyze the seasonal to interannual variability, we subtract the Ekman transport (Figure S2) from the observed AMOC time series (we will refer to this quantity as AMOCEkman). This removes short-term variability and leaves the internal, non-Ekman part of the circulation, which dominates the northward heat transport [Johns et al., 2011]. There is northward Ekman transport at $26^{\circ} \mathrm{N}$, so removing the 

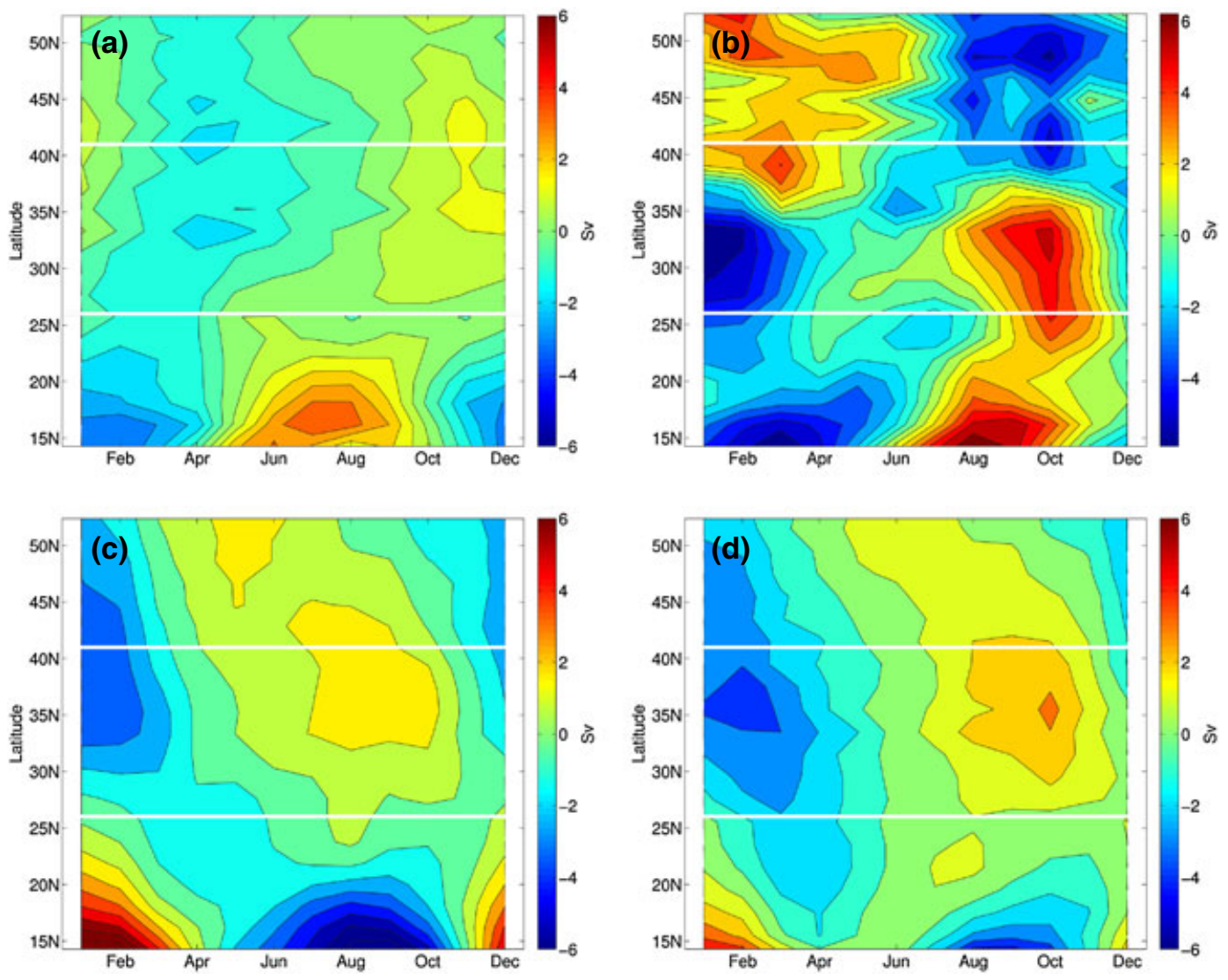

Figure 3. Hovmoeller plots of the mean annual cycle anomalies of AMOC and transport components calculated from the STORM run: (a) AMOC-Ekman, (b) Sverdrup transport, (c) Ekman transport, (d) AMOC.

Ekman transport from the observed AMOC decreases the time-mean value to about $15 \mathrm{~Sv}$. At $41^{\circ} \mathrm{N}$, the Ekman transport is southward, and the observed AMOC-Ekman has a time-mean value of almost $16 \mathrm{~Sv}$.

[12] In the observations, we generally find an inverse phasing between AMOC-Ekman at $26^{\circ} \mathrm{N}$ and $41^{\circ} \mathrm{N}$ (Figure 2a). One exception is the winter of 2009/10, where AMOC-Ekman is in phase between the two latitudes. In contrast, the modelled AMOC-Ekman has a positive correlation between the two latitudes (Figure 2a).

[13] The Sverdrup transport is inversely phased between $26^{\circ} \mathrm{N}$ and $41^{\circ} \mathrm{N}$ (Figure 2b). Directly comparing model and observations reveals a statistically significant positive correlation between observations and model for AMOC-Ekman at $26^{\circ} \mathrm{N}$ (correlation coefficient: $0.44, p<0.01$ ), but not at $41^{\circ} \mathrm{N}$. Subtracting the Ekman transport from the Sverdrup transport does not influence our results.

[14] The AMOC-Ekman and Sverdrup transport time series are dominated by the seasonal cycle (Figures $2 \mathrm{c}$ and $2 \mathrm{~d}$, see Table 1 for the seasonal range) in all cases. Although the available observed time series are only 5.5 years at $26^{\circ} \mathrm{N}$ and 8.5 years at $41^{\circ} \mathrm{N}$, we compute the mean seasonal cycles from the observations. Similarly, we compute the mean seasonal cycles from the model for the period that overlaps with the $41^{\circ} \mathrm{N}$ observations. The seasonal cycle computed for the period that overlaps with the $26^{\circ} \mathrm{N}$ observations is not significantly different (Figure S4). We choose to use the same time period for both modelled latitudes to allow for a direct comparison. At $26^{\circ} \mathrm{N}$, the AMOC-Ekman seasonal cycle has a maximum in autumn and a minimum in spring in both model and observations. At $41^{\circ} \mathrm{N}$, the model AMOCEkman seasonal cycle also has a maximum in autumn and a minimum in spring, but the observed AMOC-Ekman seasonal cycle has a maximum in spring and a minimum in autumn.

[15] Model and observations agree on the AMOC-Ekman seasonal cycle at $26^{\circ} \mathrm{N}$, but at $41^{\circ} \mathrm{N}$, AMOC-Ekman shows an inverse phasing between model and observations. The Sverdrup transport seasonal cycle agrees with the observed AMOC-Ekman seasonal cycle at both latitudes: At $26^{\circ} \mathrm{N}$, the maximum occurs in autumn and the minimum occurs in spring, while at $41^{\circ} \mathrm{N}$ the maximum occurs in autumn. The seasonal cycle agrees for all transports between model and observations for $26^{\circ} \mathrm{N}$, but only for the Sverdrup transport for $41^{\circ} \mathrm{N}$.

[16] The seasonal cycle for AMOC-Ekman emerges clearly from the noise in both model and observations, but results for the Sverdrup transport should be treated with caution, as the amplitude is not as robust as for AMOC-Ekman (Figure S3). For the model, time series for all transports are available starting in 1948, and we find that the seasonal cycles computed with only the period that overlaps with the $41^{\circ} \mathrm{N}$ observations does not differ significantly from the model seasonal cycles since 1948. The Sverdrup transport seasonal cycle agrees well with the findings by Atkinson et al. [2010], although they use a longer time series (1980-2007).

[17] In the model, we can also analyze the seasonal cycle of all transports at latitudes between $26^{\circ} \mathrm{N}$ and $41^{\circ} \mathrm{N}$. AMOC-Ekman (Figure $3 \mathrm{a}$ ) is in phase across all latitudes 

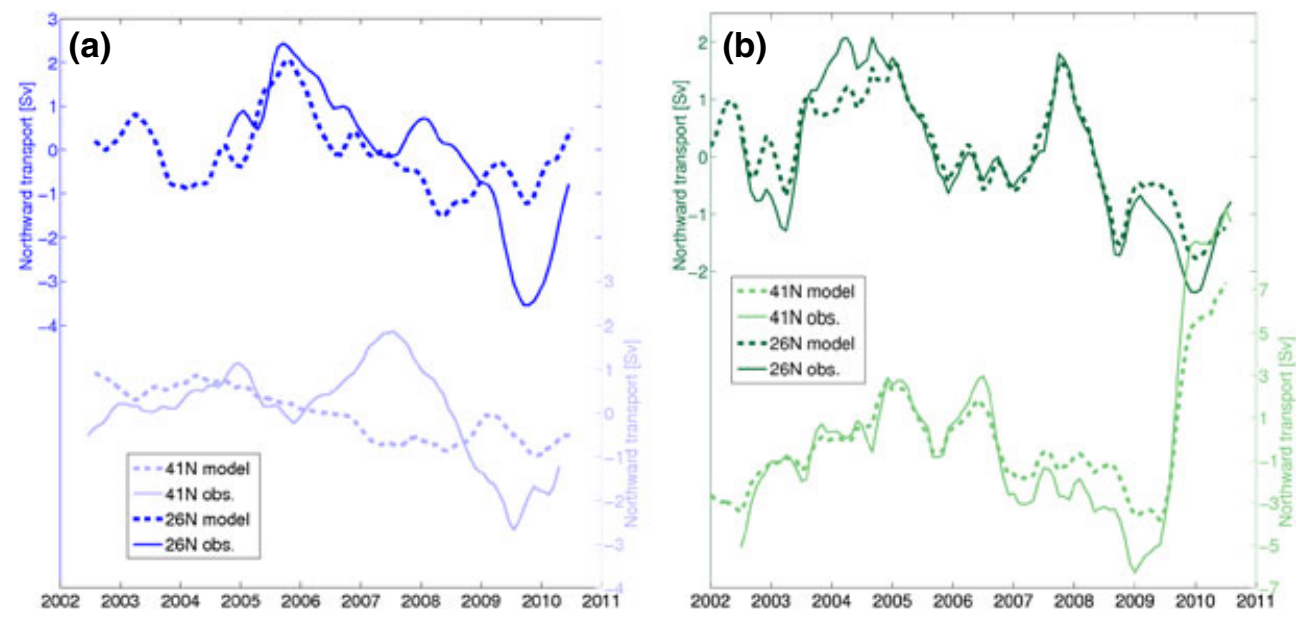

Figure 4. Interannual variability in the observed (solid) and model (dashed) time series of AMOC-Ekman and Sverdrup transport at $26^{\circ} \mathrm{N}$ (dark) and $41^{\circ} \mathrm{N}$ (light) with annual cycle removed, smoothed by a 11-month running mean: (a) AMOC-Ekman, (b) Sverdrup transport.

north of about $23^{\circ}$ N. For the Sverdrup transport (Figure $3 b$ ), there is an inversion of the seasonal cycle at about $35^{\circ} \mathrm{N}$ : north of $35^{\circ} \mathrm{N}$, the seasonal cycle shows a maximum in spring, while south of $35^{\circ} \mathrm{N}$, the maximum transport occurs in autumn. This is due to changes in the meridional wind stress at the eastern boundary north of $35^{\circ} \mathrm{N}$ and is therefore not apparent in the Ekman transport seasonal cycle (Figure 3c). The AMOC seasonal variability (Figure 3d) is dominated by the Ekman transport. As a consequence, the AMOC-Ekman seasonal cycle has a smaller amplitude than the AMOC seasonal cycle at all latitudes, and the maximum transport occurs later in the year for AMOC-Ekman at each latitude. Figure 3 also demonstrates that the exact choice of latitude (e.g., $41^{\circ} \mathrm{N} \pm 5^{\circ}$ ) is not important in the model.

\section{Latitudinal Dependence at Interannual Timescales}

[18] We remove the seasonal cycle from all time series and apply an 11-month running mean to remove the remaining seasonality from the time series (Figures 1d and 4). There is no clear relation between the two latitudes for the Sverdrup transport. In the observations, we find an inverse phasing between $26^{\circ} \mathrm{N}$ and $41^{\circ} \mathrm{N}$ for $2005-2008$ for AMOC-Ekman. But in 2009-2010, there is agreement for AMOC-Ekman between the latitudes. In contrast to the observations, there appears to be no relation between the two latitudes for the modelled AMOC-Ekman time series.

[19] The winter of 2009/2010 stands out in the anomaly time series, with a pronounced minimum in AMOC and Ekman transport at both latitudes in both model and observations (least prominent in the Ekman transport at $41^{\circ} \mathrm{N}$ ). This is likely caused by an extreme negative NAO index in that winter [Jung et al., 2011]. The minimum occurs in autumn at $41^{\circ} \mathrm{N}$ and in the beginning of 2010 at $26^{\circ} \mathrm{N}$ in both model and observations. At both latitudes, the AMOC minimum is a little earlier in the observations than in the model, and we observe a pronounced minimum of AMOCEkman in autumn, which is not apparent in the model. The Sverdrup transport at $26^{\circ} \mathrm{N}$ shows no anomaly, while there is a prominent maximum at $41^{\circ} \mathrm{N}$ in both model and observations.

\section{Summary and Conclusions}

[20] In the observations, we find opposing annual cycles for AMOC-Ekman at the two investigated latitudes: At $26^{\circ} \mathrm{N}$, AMOC-Ekman has a maximum in autumn and a minimum in spring, at $41^{\circ} \mathrm{N}$, the maximum occurs in spring and the minimum occurs in autumn. The same inverse phasing is also apparent in the Sverdrup annual cycle. By contrast, we find the same seasonality for the modelled AMOC-Ekman at $26^{\circ} \mathrm{N}$ and $41^{\circ} \mathrm{N}$, with a maximum in autumn and a minimum in spring.

[21] It is, at this point, unclear why model and observations agree on AMOC-Ekman at $26^{\circ} \mathrm{N}$, but not at $41^{\circ} \mathrm{N}$. In their comparison of several ocean reanalyses, Munoz et al. [2011] find similar seasonal cycles for the AMOC, and further studies using oceanic state estimates or further models might also be able to shed light on this issue. In addition, AMOC observations at different latitudes, especially between $26^{\circ} \mathrm{N}$ and $41^{\circ} \mathrm{N}$, will be useful in determining the reasons for the inverse phasing of AMOC-Ekman at $26^{\circ} \mathrm{N}$ and $41^{\circ} \mathrm{N}$, and whether it is gyre-specific or switches phase as does the Sverdrup transport. Tests of the $41^{\circ} \mathrm{N}$ observing system in high-resolution models, as have been done extensively for the RAPID array [Hirschi et al., 2003; Baehr et al., 2004], might shed further light on the discrepancies between model and observations. Understanding these discrepancies in the simulation of the seasonal cycle will be crucial as medium-term climate predictions inherently rely on the meaningful predictions of modulations of the seasonal cycle.

[22] While further studies are required, our results suggest that the non-Ekman part of the AMOC and its seasonal cycle is meridionally covariable on seasonal and interannual timescales. The AMOC's covariability on seasonal timescales has not been the subject of many studies to date, but coherence on interannual timescales has been identified in model analyses [Balan Sarojini et al., 2011; Bingham et al., 2007]. Both of these studies find correlation lengths that are in line with our results. Longer observational time series are needed to identify possible lead-lag relationships on timescales longer than interannual. 
[23] An implication of this is the possibility of capturing seasonal AMOC variability throughout the North Atlantic away from the specific latitude of measurements. Specifically, the $26^{\circ} \mathrm{N}$ observations might be used for inferring the seasonal AMOC variability at mid-latitudes, where it is relevant for the climate of Western Europe. Our findings also offer the prospect of investigating seasonal heat storage and ocean convergence and divergence, and thus further our understanding of the relationship of the AMOC with sea surface temperature and climate indices such as the NAO.

[24] Acknowledgments. We thank Stuart Cunningham, Shane Elipot, Stefan Gary and Jochem Marotzke for helpful discussions. We thank the two reviewers for constructive comments in the review process of the manuscript, and Irina Fast and Helmuth Haak for their help with the model output and the interpolation. We also thank Josh Willis and Will Hobbs for providing the $41^{\circ} \mathrm{N}$ data. Data from the RAPID-WATCH/MOCHA monitoring project are funded by the Natural Environment Research Council (NERC) and National Science Foundation (NSF) and are freely available from www.noc.soton.ac.uk/rapidmoc. Florida Current transports estimates are funded by the National Oceanic and Atmospheric Administration (NOAA), and are available from www.aoml.noaa.gov/phod/floridacurrent. The STORM/NCEP simulation is part of the German STORM consortium project and has received financial support from the Institute of Coastal Research of the Helmholtz Zentrum Geestacht and the Alfred Wegener Institute for Polar and Marine Research. This work is supported by the International Max Planck Research School on Earth System Modelling (IMPRS-ESM), Hamburg, (CM) and the Cluster of Excellence "CliSAP" (EXC177), University of Hamburg, funded through the German Science Foundation (DFG) (JB).

\section{References}

Atkinson, C. P., H. L. Bryden, J. Hirschi, and T. Kanzow (2010), On the seasonal cycles and variability of Florida Straits, Ekman and Sverdrup transports at $26^{\circ} \mathrm{N}$ in the Atlantic Ocean, Ocean Sci., 6, 837-859, doi: $10.5194 /$ os-6-837-2010.

Baehr, J., J. Hirschi, J. O. Beismann, and J. Marotzke (2004), Monitoring the meridional overturning circulation in the North Atlantic: A modelbased array design study, J. Mar. Res., 62, 283-312.

Baehr, J., S. Cunningham, H. Haak, P. Heimbach, T. Kanzow, and J. Marotzke (2009), Observed and simulated estimates of the meridional overturning circulation at $26.5^{\circ} \mathrm{N}$ in the Atlantic, Ocean Sci., 5 , 575-589, doi:10.5194/os-5-575-2009.

Balan Sarojini, B., J. M. Gregory, R. Tailleux, G. R. Bigg, A. T. Blaker, D. R. Cameron, N. R. Edwards, A. P. Megann, L. C. Shaffrey, and B. Sinha (2011), High frequency variability of the Atlantic meridional overturning circulation, Ocean Sci., 7, 471-486, doi:10.5194/os-7-471-2011.

Bingham, R. J., C. W. Hughes, V. Roussenov, and R. G. Williams (2007), Meridional coherence of the North Atlantic meridional overturning circulation, Geophys. Res. Lett., 34, L23606, doi:10.1029/2007GL031731.

Böning, C. W., C. Dieterich, B. Barnier, and Y. Jia (2001), Seasonal cycle of meridional heat transport in the subtropical North Atlantic: A model intercomparison in relation to observations near $25^{\circ} \mathrm{N}$, Prog. Oceanogr., 48, 231-253, doi:10.1016/S0079-6611(01)00006-4.

Bryan, K. (1982), Seasonal variation in meridional overturning and poleward heat transport in the Atlantic and Pacific Oceans: A model study, $J$. Mar. Res., 40, 39-53.

Cunningham, S. A. et al. (2007), Temporal variability of the Atlantic meridional overturning circulation at $26.5^{\circ} \mathrm{N}$, Science, $317,935-938$, doi: $10.1126 /$ science. 1141304

Dee, D. P. et al. (2011), The ERA-Interim reanalysis: Configuration and performance of the data assimilation system, Q. J. Roy. Meteor. Soc., 137, 553-597, doi:10.1002/qj.828.
Ganachaud, A., and C. Wunsch (2003), Large-scale ocean heat and freshwater transports during the World Ocean Circulation Experiment, J. Climate, 16, 696-705, doi:10.1175/1520-0442(2003)016 〈0696:LSOHAF $\rangle$ 2.0.CO;2.

Hirschi, J., J. Baehr, J. Marotzke, J. Stark, S. Cunningham, and J. O. Beismann (2003), A monitoring design for the Atlantic meridional overturning circulation, Geophys. Res. Lett., 30, 1413, doi:10.1029/ 2002GL016776.

Johns, W. E. et al. (2011), Continuous, array-based estimates of Atlantic ocean heat transport at $26.5^{\circ} \mathrm{N}, J$. Climate, 24, 2429-2449, doi: 10.1175/2010JCLI3997.1.

Jung, T., F. Vitart, L. Ferranti, and J.-J. Morcrette (2011), Origin and predictability of the extreme negative NAO winter of 2009/10, Geophys. Res. Lett., 38, L07701, doi:10.1029/2011GL046786.

Jungclaus, J. H., N. Keenlyside, M. Botzet, H. Haak, J.-J. Luo, M. Latif, J. Marotzke, U. Mikolajewicz, and E. Roeckner (2006), Ocean circulation and tropical variability in the coupled model ECHAM5/MPI-OM, $J$. Climate, 19, 3952-3972, doi:10.1175/JCLI3827.1.

Kalnay, E. et al. (1996), The NCEP/NCAR 40-year reanalysis project, B. Am. Meteorol. Soc., 77, 437-471, doi:10.1175/1520-0477(1996)077 〈0437:TNYRP $\rangle$ 2.0.CO;2.

Kanzow, T., S. A. Cunningham, D. Rayner, J. Hirschi, W. E. Johns, M. O. Baringer, H. L. Bryden, L. M. Beal, C. S. Meinen, and J. Marotzke (2007), Observed flow compensation associated with the MOC at $26.5^{\circ} \mathrm{N}$ in the Atlantic, Science, 317, 938-941, doi:10.1126/science.1141293.

Kanzow, T. et al. (2010), Seasonal variability of the Atlantic meridional overturning circulation at $26.5^{\circ} \mathrm{N}, J$. Climate, $23,5678-5698$, doi: 10.1175/2010JCLI338.

Lozier, M. S., V. Roussenov, M. S. C. Reed, and R. G. Williams (2010), Opposing decadal changes for the North Atlantic meridional overturning circulation, Nat. Geosci., 3, 728-734, doi:10.1038/ngeo947.

Marsland, S. J., H. Haak, J. H. Jungclaus, M. Latif, and F. Röske (2003), The Max-Planck-Institute global ocean/sea ice model with orthogonal curvilinear coordinates, Ocean Model., 5, 91-127, doi:10.1016/S14635003(02)00015-X.

McCarthy, G., E. Frajka-Willams, W. E. Johns, M. O. Baringer, C. S. Meinen, H. L. Bryden, D. Rayner, A. Duchez, C. Roberts, and S. A. Cunningham (2012), Observed interannual variability of the Atlantic meridional overturning circulation at $26.5^{\circ} \mathrm{N}$, Geophys. Res. Lett., 39 , L19609, doi:10.1029/2012GL052933.

Munoz, E., B. Kirtman, and W. Weijer (2011), Varied representation of the Atlantic meridional overturning across multidecadal ocean reanalyses, Deep-Sea. Res. Pt. II, 58, 1848-1857, doi:10.1016/j.dsr2.2010.10.064.

Rayner, D. et al. (2011), Monitoring the Atlantic meridional overturning circulation, Deep-Sea Res. Pt. II, 58, 1744-1753, doi:10,1016/ j.dsr2.2010.10.056.

Sutton, R. T., and D. L. R. Hodson (2005), Atlantic Ocean forcing of North American and European summer climate, Science, 309, 115-118, doi: 10.1126/science. 1109496

Taws, S. L., R. Marsh, N. C. Wells, and J. Hirschi (2011), Reemerging ocean temperature anomalies in late-2010 associated with a repeat negative NAO, Geophys. Res. Lett., 38, L20601, doi:10.1029/ 2011 GL048978.

von Storch, J. S., C. Eden, I. Fast, H. Haak, D. Hernández-Deckers, E. Maier-Reimer, J. Marotzke, and D. Stammer (2012), An estimate of the Lorenz energy cycle for the world Ocean based on the $1 / 10^{\circ}$ STORM/NCEP simulation, J. Phys. Oceanogr., 42, 2185-2205, doi: 10.1175/JPO-D-12-079.1

Willis, J. K., and L.-L. Fu (2008), Combining altimeter and subsurface float data to estimate the time-averaged circulation in the upper ocean, $J$. Geophys. Res., 113, C12017, doi:10.1029/2007JC004690.

Willis, J. K. (2010), Can in situ floats and satellite altimeters detect longterm changes in Atlantic Ocean overturning? Geophys. Res. Lett., 37, L06602, doi:10.1029/2010GL042372.

Zhang, R., and T. L. Delworth (2006), Impact of Atlantic multidecadal oscillations on India/Sahel rainfall and Atlantic hurricanes, Geophys. Res. Lett., 33, L17712, doi:10.1029/2006GL026267. 